\title{
CONFERENCE OF THE GREATER LONDON AUTHORITIES
}

Outside in the lobby one heard the comments of the harassed councillor. "Conferences! we have had nothing else but conferences this last six years! Let's get to work."

Inside the meeting at the Caxton Hall on November 25th, however, the workmanlike grip of Mr. John Burns was on the Conference of the 80 local authorities which constitute "Greater London," and the purpose of the business in hand began, under his guidance, to show itself clearly. In a characteristic opening speech he explained that the object was to bring order out of chaos and to produce " a considered and harmonious idea over all the districts and through all the districts of this London of ours, and to save the future from the costly blunders of the past."

In the past 10 years, he said, $£ 104,000,000$ had been spent on highways in England and Wales, $£ 26,000,000$ of this having been spent by County Councils.

London in 10 years had spent $£ 18,000,000$ on its highways, or $£ 1,800,000$ a year. Road improvements were a costly business, but delay might be even more costly. Greater London was filling up with tremendous rapidity. In six years only, 1,100 streets had been constructed and 75,000 houses erected, while over 300,000 acres had become absorbed in the urban area. In other words, during six years a city of nearly 400,000 people had sprung up. Nothing had given him greater pleasure than to see in the papers that Wimbledon had decided to acquire 175 acres of Wimbledon Park - a move in the right direction indeedbut much more was wanted to complement and supplement the 404 garden squares which already existed in London.

He did not think any new authority for Town Planning was necessary. His suggestion was that sectional conferences of adjoining authorities, or in groups of six, eight, or ten authorities should be called by the Local Government Board to consider the alignment of the proposed arterial roads and to agree if possible on some skeleton scheme. There was no need to construct the roads right away; in Mr. Burns' forcible language, "It is less cash that is wanted than ideas! Foresight is infinitely more value than money!" As President of the Local Government Board he was able to take a view of the position from a hill-top, and he wanted the Conference, too, to take a broad hill-top view of the situation. Mr. Burns instanced that out of the 80 authorities of Greater London, no less than 38 were at work on different stages of Town Planning, and 
11 of these had actually submitted proposals referring in all to 23,000 acres, and these schemes were well on their way to approval.

There was still a great deal to be done though, and even in the County of London itself, out of a total area of 74,000 acres of the L.C.C. area, there were still 12,000 acres without houses on them.

The city of Birmingham had prepared five Town Planning schemes, any one of which might be a model for the Greater London areas, and those schemes provided.for roads of all widths from 18 feet wide to 100 feet. Birmingham had used the Town Planning Act to help not only in widening roads but in making new roads as well as in alignment and diversion. In the next 25 years there ought to be in the appearance of -streets and roads a tremendous advance, and they ought to make London what Sir William Dunbar called 400 years ago "The flower of cities all."

The ratepayer must be considered, of course, but in thinking of State aid, they must not forget that the ratepayer and the taxpayer were one and the same individual-with two pockets perhaps, but only one banking account.

Sir Aston Webb, who opened the discussion on behalf of the Royal Institute of British Architects and other professional bodies, touched the right note at once and emphasized the urgent necessity, not necessarily for a new authority, but for giving some central authority power to deal with the main arterial roads out of London, and to consider the many broader questions which were bound up with the question of the main roads. The suggested district conferences might be all right in their way, but in the last resort there must be some power to say "This road shall go here."

Sir Alexander Stenning supported this view on behalf of the Surveyor's Institution.

Lord Peel, chairman of the L.C.C. Improvements Committee, said the L.C.C. were spending $£ 900,000$ a year on interest and sinking fund for past improvements, so they at least had not been idle.

The Chairman of the Finchley Urban District Council made an important contribution to the discussion in pointing out that something more than main roads must be considered. That Council, with the help of Mr. Raymond Unwin, are preparing a Town Planning scheme for a thousand acres of undeveloped land, and what do they find ? A proposed railway-the Northern Junction Railwayis again submitted to Parliament and will, if constructed, cut right across the Town Planning scheme. What seems to be really wanted is some central authority which shall say "Here shall your new roads go " and "There shall your railways go, and nowhere else." 
Alderman Thompson, of Richmond, said he had a mandate from 50 out of the 80 authorities of Greater London to ask that district conferences should be called and the local authorities would be glad to have the skilled help of the great Architects' and Surveyors' Societies, "if," he slyly added, "they will give it for nothing."

"Which they will do," came from Mr. Burns.

Another important point was the consolidation of the powers of the various Government departments dealing with arterial roads, town planning and transit. As regards cost he thought an estate road should be paid for by the estate; a district road by the district; a county road by the county; and a national road by the nation.

Another very important matter was that power was wanted by local authorities to say what class of traffic should be allowed on particular roads, in other words to control traffic.

As Mr. Gordon, of the L.C.C., well said in advocating a central authority: "The essence of the problem is for one point of view in the interests of the whole; if each authority is to have its own little way, how on earth is unity of view to be obtained?"

Mr. H. R. Aldridge, the well-known secretary of the National Housing Council, deprecated the introduction of any new authority, which must of necessity raise political problems. In Paris, for instance, this same question was causing endless delay and preventing the sweeping away of the old ring of fortifications which was throttling its growth. In Berlin, too, with its many outlying authorities, the position is absolute chaos. He pointed out that the undoing of the mistakes of the past could not be applied to the built-up areas without an amendment of the Town Planning Act which, at present, only dealt with land still unbuilt on. The L.C.C. however ought to put their house in order as regards the Town Planning of the 12,000 acres still unbuilt upon within their area.

A suggestion, too, which may be worth considering, was made by $\mathrm{Mr}$. William Crow, mayor of West Ham, who said with all the will in the world the poor districts of East London could not find the money to make new arterial roads, and he suggested a special rate for this purpose over the whole area of Greater London.

A striking example of present incomplete methods was given by $\mathbf{M r}$. W. H. Seth-Smith, F.R.I.B.A., who instanced the proposed Croydon bypass road, both ends of which when constructed would be bottle necked, crippled and tortuous.

As the discussion proceeded, it became evident that the general opinion was that not a central authority, but a centralising authority, was wanted, a representative authority composed of delegates from all the authorities being clearly too unwieldly. 
A suggestion was indeed made that a board of experts would be best, but the London traffic problem and the question of Town Planning in Greater London is one and the same thing, and that a new Government department should be made for the job. In any case, some assurance was wanted as to the eventual completion of these through communicating roads. If local conferences were to be held, it was important too that the various Government authorities should be included in each conference.

Mr. Raymond Unwin, who was the first speaker after the luncheon interval, emphasized the important point that the local conferences, when held, must not be exclusively Road conferences, but Town Planning conferences, and should consider the whole question including possible open spaces in the lines advocated by the London Society, and also the architectural effect of the whole.

There was too the possible necessity of compulsion to make local authorities take steps to promote a town planning scheme and thus secure control over the development of their area. And there was the still further necessity of somebody who can render the decisions of the local conferences effective-some final power not only to provide the big ideas but to put them into effect. A time limit should be put on the local authorities and they should, if necessary, be made to take action in the matter.

With regard to cost it should be remembered that the lines of the roads have first to be settled. The last thing that has to bu done is to make the road.

Many of the speakers apparently found a difficulty in discriminating between the Road Board and the London Traffic Branch of the Board of Trade, but speaker after speaker got up to drive home the point that the Town Planning central authority should also be the Road central authority. The want of a general plan was painfully evident in the construction of the London tube railways, all of which had been made within the last few years. The value of property too was increasing in a phenomenal way which rendered it essential to take early action; for instance the value of property on the north side of Oxford Street was now 90 per cent. higher than it was 10 years ago, owing to the erection of great blocks of business premises.

A forcible contribution to the discussion was made by Sir George Gibb, chairman of the Road Board, who said there seemed to be an erroneous idea that his department had vast hoarded millions still to dispose of. The position was quite the reverse, and he for one was very glad to hear the president say that "it is less cash that is wanted than ideas."

Up till the 31st October, 1913, the income of the Road Board had been 
roughly $£ 4,000,000$, out of which $£ 800,000$ had been set aside, as required by the Act, against times of trade depression, grants had been promised amounting to $£ 2,855,000$, and loans $£ 984,000$, so that they were actually on the wrong side.

It should be remembered too that this was for the whole kingdom. The contribution received from the County of London for license duties amounted to only $£ 17,000$ per annum, though the petrol duties, mainly paid by motor buses, amounted to probably $£ 150,000$ per annum.

In summing up the discussion Mr. John Burns said he would endeavour to reply to a few of the hints and one or two of the mandates that had been scattered about in such felicitous terms. If this Conference had done nothing better than to bring together the ministers and permanent officials of Government departments to be pilloried together, it had not been without considerable service. It did public departments a great deal of good to come directly into contact with the representatives of the public, but the Local Government Board, the Road Board, and the Traffic Branch of the Board of Trade could not go on playing the game of "Box and Cox," and saying, "That's not in my department!" In this kind of conference the platform derives more good than the audience.

"The play of Box and Cox would have to be taken off the bills."

Mr. Burns humorously said that his knowledge of London, like Mr. Sam Weller's, was " extensive and peculiar," and he had noticed in going about innumerable obstructions at many important street junctions such as sandbins, approaches to underground lavatories, and what not, and at many of these places valuable space could easily be added to the streets. He thought the critics who objected to traffic from other districts using their roads had forgotten the injunction to bear one another's burdens.

No formal resolutions would be put to the conference, but it was generally agreed

That this Conference agrees to local conferences being called:

That the Local Government Board should convene these conferences and should draft a general reference on the subject:

That an official report of the Conference should be circulated as soon as possible :

That he was prepared to urge the local authorities who have not already prepared Town Planning schemes to do so:

Finally that the existing central authorities should get together, pending "probable absorption of each by one another" as subsequent circumstances may determine.

W. R. DAVIDGE. 